AperTO - Archivio Istituzionale Open Access dell'Università di Torino

Early child care experiences and individual differences: the role of gender and temperament in social skills and problem behaviours in Italian toddlers

This is a pre print version of the following article:

Original Citation:

Availability:

This version is available http://hdl.handle.net/2318/1723699 since 2020-01-17T08:33:02Z

Published version:

DOI:10.1080/03004430.2019.1655736

Terms of use:

Open Access

Anyone can freely access the full text of works made available as "Open Access". Works made available under a Creative Commons license can be used according to the terms and conditions of said license. Use of all other works requires consent of the right holder (author or publisher) if not exempted from copyright protection by the applicable law. 


\title{
Early child care experiences and individual differences: the role of gender and temperament in social skills and problem behaviors in
}

\section{Italian toddlers}

\author{
Angelica Arace ${ }^{a *}$, Donatella Scarzello ${ }^{\mathrm{a}}$, Paola Zonca ${ }^{\mathrm{a}}$, Protima Agostini ${ }^{\mathrm{a}}$ \\ ${ }^{a}$ Department of Philosophy and Educational Sciences, University of Turin, Italy \\ *corresponding author: angelica.arace@unito.it; Department of Philosophy and \\ Educational Sciences, University of Turin, Via Gaudenzio Ferrari 9, 10124 Turin, Italy
}

Angelica Arace is professor in Developmental and Educational Psychology at University of Turin. Her research interests are infancy socio-emotional development, early childcare, childcaregivers attacchment, assessment of parenting competence and quality of educational contexts.

Donatella Scarzello is researcher in Developmental and Educational Psychology at University of Turin. Her studies concern the assessment of parenting competence and the promotion of well-being in educational contexts.

Paola Zonca is researcher in Childhood education at University of Turin. Her research interests are early childhood education and care, parents involvement and educators efficacy.

Protima Agostini is pedagogist and research fellow in Developmental and Educational psychology at University of Turin. Her research interests are early childhood education and care, assessment of parenting competence and attachment relationship. 


\title{
Early child care experiences and individual differences: the role of gender and temperament in social skills and problem behaviors in Italian toddlers
}

\begin{abstract}
Research on the effects of nursery school attendance still presents divergent results: a possible explanation is that the effects of child care on development outcomes can be modulated by individual characteristics, such as gender or temperament. In the present study, gender differences in nursery adaptation (evaluated by social skills and behavioral problems) have been explored: participants are 525 toddlers, attending 32 nursery schools with similar levels of quality in a large city in northern Italy. Associations with age of enrolment, hours of attendance and child temperament have also been analyzed. Results indicate that males are more vulnerable than females: spending more time in the nursery increases the risk of behavioral problems in males but not in female, and an early enrolment (under one year of age) results in greater relational skills only for females. Difficult temperamental traits are also associated with behavioral problems with genderspecific aspects. Educational implications are discussed.
\end{abstract}

Keywords: early child care; gender differences; temperament; social skills; toddlers.

\section{Introduction}

In many Western countries the cultural and scientific debate on the effects of nursery school attendance on the development and well-being of children continues to be "a persistent question, with elusive answers" (Shpancer, 2006, p. 227). While there is some agreement that attending nursery school has positive effects on cognitive and linguistic development (Belsky, Bakermans-Kranenburg, \& Van IJzendoorn, 2007; Del Boca, Pasqua, \& Suardi, 2015; NICHD Early Child Care Research Network, 2002; VotrubaDrzal, Coley, Koury, \& Miller, 2013), the data regarding social development are not as consistent: some studies report positive effects (Crockenberg \& Leerkes, 2005), while other studies fail to find any effect at all (Deater-Deckard, Pinkerton,\& Scarr, 1996), and another share of them points out negative effects, such as an increase in externalizing 
problems and stress levels in children (Drugli et al., 2018; McCartney et al., 2010; Pluess \& Belsky, 2009).

An explanation for these findings could be the "differential susceptibility" (Belsky et al., 2007; Broekhuizen, vanAken, Dubas, Mulder, \& Lesemanb, 2015): children differentiate themselves in the measure in which they are influenced - for better or for worse - by care experiences, both within the family and in educational contexts. According to Crockenberg (2003), this differential susceptibility would explain, for example, why only some children show an increase in behavioral problems when exposed to low-quality child care, while many others are only marginally affected. Differential susceptibility could also explain why several studies have demonstrated that more hours in day-care are related to higher levels of externalizing behavior (Loeb, Bridges, Bassok, Fuller, \& Rumberger, 2007), while other researches claim that only some children are negatively influenced by the number of hours spent at the nursery school (Watamura, Donzella, Alwin, \& Gunnar, 2003).

The evidence of a susceptibility that is differential towards the environment has given impetus to numerous studies regarding the intersection between child care quality and child characteristics: among these, gender and temperament are the variables on which the scientific debate has been focusing the most, with still conflicting search results.

Regarding gender, in some studies gender did not accounted for differences in child behaviors in the nursery context (Belsky et al., 2007; Burchinal, Peisner-Feinberg, Bryant, \& Clifford, 2000; Lemay, Bigras, \& Bouchard, 2014), but many other studies have instead found that males have more difficulties in adapting to the contexts of extrafamily child care. For example, low-quality child care is strongly associated with the presence of behavioral problems in males, while the same association is weak or non- 
existent for females (Howes \& Olenick, 1986; Votruba-Drzal, Coley, MaldonadoCarreño, Li-Grining, \& Chase-Lansdale, 2010). Females also appear to have an advantage over males in various domains of development that are especially important in a nursery context. In fact, they are more independent, better at regulating themselves and communicating (Meece \& Painter, 2008; Meland, Kaltvedt, \& Reikerås, 2016; Zambrana, Ystrom, \& Pons, 2012).

According to other studies, even temperament influences the ability of children to adapt to the context of care. Temperament refers to the general pattern of how children will react to and interact with their environment which is present from birth. Thomas and Chess extensively researched child temperament in the late 1970s and identified nine dimensions or qualities that help indicate temperament, including: activity level, rhythmicity, distractibility, approach or withdrawal, adaptability, attention span and persistence, intensity of reaction, threshold of responsiveness, and quality of mood (Thomas \& Chess, 1977). According to the authors, there are three general types of temperaments in children: easy, slow-to-warm, and difficult. Easy children are generally happy, active children and adjust easily to new situations and environments. Slow-towarm children are generally mellow, less active, and can have some difficulty adjusting to new situations. Difficult children have irregular habits and biological routines (e.g., eating, sleeping), have difficulty adjusting to new situations, and often express negative moods very intensely.

Temperament is a strong predictor of several aspects of social functioning in different age of life (Eisenberg, Fabes, Guthrie, \& Reiser, 2002; Séguin \& MacDonald, 2018) and many studies in the last two decades have analyzed the interaction between environmental characteristics and the socio-emotional development of children, mediated by temperamental traits. According to Eisenberg, Vaughan, \& Hofer (2009), for example, 
the temperament of the child influences the quality of social behavior with peers and the friendship bonds. Some temperamental traits, such as withdrawal and negative emotionality, can make the child more vulnerable to stress in the child care context (Dettling et al., 2000; Watamura et al., 2003). They also mediate the effects of certain structural aspects of child care, such as early enrolment during the first year of life or fulltime attendance, variables that correlate with the presence of internalizing and externalizing problems, mostly in toddlers with difficult temperament (Beijers, RiksenWalraven, Putnam, de Jong, \& Weerth, 2013; Crockenberg \& Leerkes, 2005), even if data are not always consistent (NICHD, 2002).

Since there are no conclusive studies on the relationships between gender, children's temperament and adaptation to nursery context (Crockenberg, 2003), also in the Italian research (Emiliani \& Molina, 2017), our study is characterized by the following research questions:

- Males and females display different levels of nursery adaptation, assessed through the level of social competence and behavioral problems?

- Adaptation of males and females is influenced in a diversified way by certain variables related to child care, such as hours of daily nursery attendance, age of enrolment and quality of the nursery service?

- Gender-specific associations between temperament and adaptation of males and females to the nursery setting can be highlighted?

Given the increasing number of children entering pre-school education and the importance of early social development for subsequent socio-emotional adjustments, it is important to investigate more deeply which individual factors can be useful to understand differential susceptibility and to predict the adaptation and well-being of children in a nursery context. 


\section{Materials and Methods}

\section{Participants}

Participants are 525 toddlers (293 males and 232 females, aged between 12 and 36 months $(\mathrm{M}=25.89 ; \quad \mathrm{SD}=5.43)$. Childrens' socioeconomic status (SES), measured using Hollingshead's (1975) scale for parental occupation and educational level, is mediumhigh $(M=46.38 ; S D=12.37)$. For each child, the mother and the reference educator were involved in the research.

Mothers are between 21 and 49 years old $(M=36.38 ; S D=4.66)$, have a high level of education (62.5\% has a university degree) and in most cases are engaged in fulltime work (64\%). The majority of mothers are Italian (86\%).

The educators are 203, almost all women (97\%) and Italian (99\%), aged between 23 and 65 years $(M=42.79 ; \mathrm{SD}=11.08)$, in most cases $(69 \%)$ in possession of a high school diploma (30\% has a university degree), with a very varied length of service (range $=4$ months to 41 years; $\mathrm{M}=17.57 ; \mathrm{SD}=11.41)$.

Table 1 summarizes the characteristics of the children, subdivided by gender: the preliminary analysis of the sample shows that there are no significant differences between males and females in age, age of enrolment and daily hours of nursery.

\section{Recruitment and procedures}

Participants were contacted after approval of the research protocol by the university ethics committee. For the present study, 40 nursery schools of a large city in Northern Italy were invited to participate: the nursery schools were selected from a larger basin of 55 schools divided into 8 districts with different demographic and socio-cultural characteristics, randomly choosing 5 schools for each district in order to guarantee the territorial representativeness of the analysis sample. 
All nursery schools contacted agreed to participate in the research. Parents of children attending schools that have joined the project were contacted by a research assistant and given written information about the present study and a consent form. Only the children whose mothers signed the consent form were involved in the research. We decided to involve only mothers because they were more than $80 \%$ of the parents that could be contacted. In this way, the same evaluator was used for all children. All reference educators instead agreed to participate in the research.

For data analysis we have further selected 32 nursery schools, on the basis of high quality indicators, so that all the nursery of the sample are homogeneous with regard to the quality standards. The evaluation of the quality standards was made through observations of the educational context through the SVANI scale, as illustrated in the measures section.

\section{Measures}

\section{Childcare quality}

Childcare quality was measured through the SVANI (Bassa Poropat \& Chicco, 2003; Harms, Cryere, \& Clifford, 1990), which was compiled by two independent observers (Cohen's Kappa = 0.87). The SVANI has been adapted to the Italian context and over the years was widely used to promote evaluation processes in early childhood services. It consists of 37 items divided into 7 subscales: 1. Furnishings and materials available to children (5 items); 2. Routine care (9 items); 3. Listening and speaking (verbal stimulations provided by the context) ( 2 items); 4 . Learning activities ( 8 items); 5. Peerto-peer interaction and interaction between adults and children (5 items); 6. Activity organization (4 items); 7. Needs of the adults (organization of spaces reserved for educators and parents) (4 items). For each item, an evaluation can be expressed on a 5point scale (from 1. Poor quality to 5. High quality). 
The nurseries selected in the sample have average scores greater than 3 in all 7 subscales, and average scores greater than 4 in at least 4 subscales (Table 2). There are no significant mean differences in the quality experienced by males and females.

\section{Child temperament}

The temperament of children was evaluated by mothers by QUIT (Italian Questionnaires on temperament) (Axia, 2002), in the 12-36 month version, consisting of 56 items describing child behavior on a 6 -point scale (from $1=$ almost never to $6=$ almost always). The QUIT has been validated in the Italian context and investigates the following characteristics: Social orientation; Inhibition to novelty; Motor activity; Positive Emotionality; Negative Emotionality; Attention.

\section{Child social competence and behavioral problems}

The social skills and behavioral problems were evaluated by the educators through the following tools:

- Questionnaire on Peer Interactions (QPI; D'Odorico, Cassibba, \& Buono, 2000; Tallandini \& Morsan, 2006), validated in the Italian context, consists of 22 items that assess the ability to interact with peers. Educators indicate the frequency of each behavior according to a 4-position Likert scale (1. "rarely" to 4. "very often"). The QPI assigns scores on four scales: 1. Negative social behaviors; 2. Positive social behaviors; 3. Difficulties in social participation; 4. Popularity. By re-encoding the items that indicate negative behavior (so that high values indicate a lower occurrence), we have also identified a global index of social skills, given by the sum of the single scores (Longobardi, Spataro, Frigerio, \& Rescorla, 2016).

- CBCL- Child Behavior Checklist/11/2-5 (Achenbach \& Rescorla, 2000), in the form for professional caregivers (Teacher's Report Form- TRF, version adapted to the Italian context), consisting of 100 questions that describe specific 
problematic behaviors. Educators assess the presence of each behavior according to a three-point Likert scale $(0=$ not true, $1=$ sometimes true, $2=$ very/often true $)$. The CBCL consists of a Total Scale, a scale of Internalizing problems and one of Externalizing problems. The CBCL also provides the score for the following subscales: Emotionally Reactive-ER, Anxious/Depressed-AD, Somatic Complaints-SC, Withdrawal-W, Attention Problems-AP, Aggressive Behaviour$\mathrm{AB}$, Other problems-OP.

\section{Data analysis}

First step in the data analysis consisted in the descriptive analysis of the sample and the variables under investigation (all variables have a normal distribution).

Gender differences in social skills, behavioral problems and temperamental traits were investigated by analyzing variance (ANOVA), while the relationship between social competence, behavioral problems and age was tested through correlation analysis ( $\mathrm{R}$ di Pearson) separately for males and females.

To assess the differences in social skills and behavioral problems based on the age of enrolment and the hours of attendance, we have dichotomized these two variables into two categories (enrolment before 12 months / enrolment after 12 months; frequency full time / frequency part-time) and applied the analysis of variance (ANOVA) separately for males and females.

IBM SPSS Statistics was used for the analysis.

\section{Results}

\section{Social skills and behavioral problems in the nursery context: gender differences}

With regard to social skills, measured through the QPI compiled by educators, the analysis of variance showed that females have a significantly higher overall social skills 
index: specifically, females show a higher number of positive social behaviors, a lower number of negative social behaviors and a lower level of difficulty in social participation. Only in the subscale of popularity there are no statistically significant differences between males and females (Table 3).

The analysis of the single items showed that the greatest differences between males and females $(p \leq 0.01)$ are found in specific behaviors, some more typically found in females ("If a schoolmate cries for any reason, the child gets close and tries to console him"; "If a schoolmate is in trouble, the child tries to help"; "The child manages to play collaboratively with a schoolmate"), while others in males ("The child is the object of physical aggression by other children"; "The child has to be stimulated by the educator/teacher before he plays with others"). Therefore, data show that females are more empathic and more likely to engage in prosocial behavior, while males are more frequently involved in conflict and more prone to social withdrawal.

With regard to behavioral problems, assessed through the CBCL compiled by the educators, the analysis of variance highlighted a higher level of behavioral problems in males (Total scale). Gender differences have been found with regard to both internalizing and externalizing issues and, more specifically, statistically significant differences have been highlighted in the following subscales: Withdrawal-W, Attention Problems-AP and Aggressive Behavior-AB, as well as in the Other Problems-OP scale (Table 4).

The analysis of the single items showed that the greatest differences between males and females $(\mathrm{p} \leq 0.001)$ concern the following items: "Fails to carry out tasks"; "Fidgets"; "Quickly shifts from one activity to another"; "Overactive"; "Can’t concentrate, can't pay attention for long"; "Particularly loud"; "Disturbs others". Such problematic behaviors are related to difficulties in self-regulation and peer relationships, and are much more frequently observed by educators in males than in females. 
In addition, we investigated whether the levels of social competence and behavioral problems vary with the age of the children. For this purpose, we analyzed Pearson's correlation separately for males and females: the results showed that, for both, the increase in age is associated with an improvement in social skills; age, on the other hand, does not seem to affect behavioral problems, neither for males nor for females; this is also confirmed by the analysis of the individual CBCL subscales (Table 5).

Moreover, the analysis of the correlation showed that social skills is negatively correlate with behavioral problems, both in males and females (Table 5). An increase in social skills, as measured by the overall CPI index, is associated with a decrease of CBCL subscales' scores, while an increase in negative social behaviors is associate with hight levels of externalizing and internalizing behavioral problems.

Social skills and behavioral problems in the nursery context: differences in the characteristics of child care

With regard to social skills, the age of enrolment affects females more significantly: an early enrolment (under one year of age) results in greater relational skills, evaluated through the overall score of the QPI. Females enrolled before the age of one display positive social behaviors more frequently $(\mathrm{F}(1,222)=10,459 ; \mathrm{p}=0,001)$ and have fewer difficulties in social participation $(F(1,225)=5,775 ; \mathrm{p}<0,05)$, while for males there are no significant differences.

The age of enrolment, on the other hand, does not affect the behavioral problems of both females and males; this is supported by the analysis of variance on the overall score of the CBCL, on the Internalizing and Externalizing scales and also on the specific subscales (Table 6).

Attending nursery school full time seems to have partially different effects for males and females: females who spend many hours at the nursery show a higher level of 
social skills, measured by the global index of the QPI. An analysis of the specific scales of QPI also shows that they engage in positive social behavior more frequently $(F(1,206)=6,358 ; \mathrm{p}<0,05)$, are more popular among peers $(\mathrm{F}(1,203)=5 ; \mathrm{p}<0,05)$ and have fewer difficulties in social participation $(\mathrm{F}(1,209)=4.759 ; \mathrm{p}<0.05)$; this last aspect is also true with regard to the male sample $(\mathrm{F}(1,259)=5.245$; $\mathrm{p}<0.05)$, for which, however, afternoon attendance also increases the risk of behavioral problems, especially of the externalizing type. In particular, the analysis on the single scales of the CBCL highlights an increase in somatic symptoms $(\mathrm{F}(1,268)=4.56 ; \mathrm{p}<0.05)$ and in other problems of various kinds $(\mathrm{F}(1,230)=4.95$ scale; $\mathrm{p}<0.05)$, and again, this only applies to males (Table $6)$.

\section{Social skills and behavioral problems in the nursery context: differences in}

\section{temperament}

In order to investigate the presence of any gender differences in temperament characteristics as evaluated by mothers, we conducted a variance analysis: data showed that females and males do not differ significantly in the aspects considered, except for the inhibition to novelties, which is greater for females (Table 7). The analysis of the single items showed that the greatest differences between males and females $(p \leq 0.001)$ concern the following behaviors, which are most frequently adopted by females: "When the child sees an unknown person, s/he shows signs of concern"; "The child takes a long time before getting close to, or smiling at an unknown person", "When the child sees a stranger, s/he frowns or shows concern".

To highlight the relationship between temperament and nursery adaptation and investigate any gender differences, we have carried out the Pearson correlation analysis between temperament characteristics as measured with QUIT, and the scores obtained with QPI and CBCL, separately for males and females. Data show that neither males nor 
females display statistically relevant associations between the social skills and temperament characteristics considered. Only for females, there is a weak positive correlation between positive social behavior and positive emotionality $(r=0.138 ; \mathrm{p}<0.05)$ and a negative correlation between positive social behavior and negative emotionality ( $\mathrm{r}$ $=-0.148 ; \mathrm{p}<0.05)$.

As far as behavioral problems are concerned, a marked temperamental tendency to motor activity is associated with a greater risk of behavioral problems. This is true for both males and females. In fact, there is a positive correlation, albeit weak, between motor activity and the overall CBCL score, both for males ( $\mathrm{r}=0.152 ; \mathrm{p}<0.05)$, and for females $(\mathrm{r}=0.190 ; \mathrm{p}<0.05)$; for males, motor activity is also positively associated with externalizing behavior $(r=0.183 ; p<0.01)$, in particular aggressive behavior $(r=0.139$; $\mathrm{p}<0.05)$ and attention problems $(\mathrm{r}=0.207 ; \mathrm{p}<0.01)$. For females, it is positively associated only with attention problems $(r=0.184 ; \mathrm{p}<0.05)$.

In addition, for males, a temperamental tendency to negative emotionality is associated with greater internalizing problems $(r=0.132 ; \mathrm{p}<0.05)$, and, in particular, with depressive anxious behavior $(\mathrm{r}=0.135 ; \mathrm{p}<0.05)$ and greater emotional reactivity $(\mathrm{r}=$ $0.169 ; \mathrm{p}<0.01)$; the propensity to inhibition to novelties is weakly associated with a greater risk of internalizing problems $(\mathrm{r}=0.131 ; \mathrm{p}<0.05)$. For females, inhibition to novelties has a more significant impact than for males: it is positively correlated with internalizing problems $(r=0.144 ; \mathrm{p}<0.05)$, and specifically with emotional reactivity $(\mathrm{r}$ $=0.141 ; \mathrm{p}<0.05)$ and depressive anxious behavior $(\mathrm{r}=0.175 ; \mathrm{p}<0.05)$. Conversely, it is negatively correlated to externalizing problems $(r=-0.151 ; \mathrm{p}<0.05)$ and in particular to aggressive behavior $(\mathrm{r}=-0.148 ; \mathrm{p}<0.05)$. 


\section{Discussion}

The analysis of gender differences with regard to social skills and behavioral problems in the nursery context confirms, in line with other studies, that females have higher levels of adaptation compared to males. In fact, females show higher levels of social competence, which is mostly expressed through a greater tendency to exhibit positive social behaviors related to prosociality and cooperation, and fewer behavioral problems, especially if externalizing, such as aggressive behaviors and attention problems. Given the same good levels of child care quality, males are therefore more vulnerable, without this vulnerability being attributable to a greater presence of difficult temperamental aspects.

This differential susceptibility of boys can be traced back to individual characteristics on the one hand, and to contextual variables typical of the nursery context on the other. According to several empirical studies, males in pre-school age have weaker self-regulatory skills than their female peers (Else-Quest, Hyde, Goldsmith, \&VanHulle, 2006). Various researches have suggested that males need very well-structured care environments with a sensitive and responsive caregiver, which acts as an external regulator of their behavior and emotions, to a greater extent than females (Crockenberg, 2003; Votruba-Drzal et al., 2010).

Moreover, according to other studies, the cognitive and perspective-taking skills necessary to implement prosocial behaviors are less developed in males (Zahn-Waxler, Radke-Yarrow, Wagner, \& Chapman, 1992). These abilities mature with age, and their increase, as highlighted in the data analysis, corresponds to an increase in social competence and a decrease in behavioral problems. This earlier maturation in females is also highlighted by studies on pre-school play, which have found a developmental gap between males and females: the former engage in solitary games more frequently, while 
the latter prefer more socially oriented forms of play, also supported by the comparatively greater linguistic skills that they show during the early years of development (Achenbach \& Rescorla, 2000). These skills make females better at regulating emotions and behavior, giving them an advantage when it comes to building positive social relationships and communicating their needs effectively to both adults and peers. Furthermore, several studies point out that females show more intense empathic reactions than males, and that they do so at an earlier age (Eisenberg \& Miller, 1987; Maccoby, 1998). This may be the result of gender differentiated parental practices: parents involve their daughters in emotional dialogues more easily, offering them more opportunities to talk and share feelings and emotions (Dunn, Bretherton, \& Munn, 1987). Family socialization practices also tend to push females towards helpful behaviors, in accordance with the social stereotypes that see females as responsible for the care and protection of the weak; conversely, they foster self-assertion and competition in males (Brody \& Hall, 2000; Chaplin, Cole, \& Zahn-Waxler, 2005).

According to Votruba-Drzal et al. (2010), the lesser adaptation of males can also be explained by contextual variables such as the level of structuring of nursery activities: in free play situations, in which the adult's scaffolding and containment play a smaller role, females tend to focus their games more on cooperation and communication, while males tend to engage in more physical, harsh and sometimes aggressive games (Fabes, Hanish, \& Martin, 2003), thus offering more opportunities for the educator to observe behaviors in terms of externalizing issues. It should also be remembered that male aggressiveness at two or three years of age is more evident, as it is manifested mostly through physical and verbal attacks. Therefore, it is usually detected by the research tools commonly used during the pre-school period. On the contrary, female aggressiveness is 
mainly relational-emotional, and thus more elusive (Crick, Ostrov, \& Werner, 2006; Ostrov \& Keating, 2004).

The social behaviors observed in the nursery context can also be influenced by gender stereotypes (Poulin-Dubois, Serbin, Eichstedt, Sen, \& Beissel, 2002) which are internalized at an early age. According to these stereotypes, males are described as more physically active, dominant and aggressive than females, while females are expected to be friendlier and kinder than males (Martin, 1995). The behavior of males and females in pre-school contexts can therefore be influenced by the expectations and gender ideals of the reference educators (Meland et al., 2016; Warrington and Younger 2006). Moreover their decision parameters in the identification of behaviors as problematic could reflect their specific roles and responsibilities (Arace, Scarzello, \& Prino, 2018): educators may have more difficulty managing the aggressiveness of males (tipically more direct and physical) and overestimate the frequency of such behaviors.

In general, males need a great investment in terms of attention from the professional caregiver, who has to take care of a significant number of children at the same time and may not always respond in a sensitive way, contributing to an increase in stress levels in males, whose abilities to regulate negative levels of arousal activation are weaker (Weinberg, Tronick, Cohn, \& Olson, 1999). The greater sensitivity to stress would also explain the fact that attending the nursery full-time has negative effects on males but not on females, as evidenced by our data, which highlight more somatic and externalizing symptoms in males who attend full-time. Even under stress, females are able to maintain good social competence levels: for them, more than for males, attending full-time seems to be an opportunity to increase their social participation and exercise their social skills. The fact that the females enrolled in the nursery before 12 months of age show higher levels of social skills can be explained both in light of the developmental 
advantage that females manifest at this age (so that females, which are more socially competent, are enrolled in pre-school educational services earlier than their male peers) and as a consequence of a more time-extensive opportunity offered by the nursery as a social training. Therefore, what appears to be an opportunity for learning for females (to attend the nursery from an early age and for a long time), can instead prove to be a source of stress for males and have a negative influence on their development compared to other types of child care.

Among the temperamental traits that can make the adaptation of males more difficult, our study highlighted the role of motor activity: higher levels of impulsiveness and psychomotor agitation are associated with attention disorders for both males and females and, in the case of male, also with greater behavioral problems, especially externalizing disorders. Therefore the higher levels of activation exhibited by males, especially after 18 months (Eaton \& Enns, 1986; Komsi et al., 2006), can become a risk factor for the adaptation. The temperamental trait of inhibition in the face of novelties can also play the role of risk factor, because is associated with higher levels of internalizing problems, for both males and females; it should be noted, however, that for females the same temperamental trait can instead decrease the adoption of externalizing and aggressive behavior, thus becoming a complex variable to consider, in its dual meaning.

The data also show that, for males, the tendency to negative emotionality is a possible risk factor with regard to internalizing problems; this is in line with the studies we have already mentioned, which highlight greater difficulties in the autonomous regulation of emotions in male children, an aspect that could decrease the ability to adapt in group contexts where adults cannot constantly perform the function of external regulators. Thus, difficult temperamental traits, albeit with gender-specific aspects, can be safely associated with behavioral difficulties. 


\section{Limitations}

The study presented has some limitations. First, social competence and behavioral problems of the child at the nursery have been evaluated only by the reference educator: to improve the validity of the evaluation, it would have been appropriate to have recourse also to an independent observer and verify the degree of agreement between the two evaluators. Second, it would have been useful to involve the fathers in the research and to verify the degree of agreement between mothers and fathers in the evaluation of the temperamental aspects of the child. There are fewer Italian studies on young children in which both parents are involved as evaluators. Third, in light of the findings, it would also have been useful to measure other individual characteristics of children, such as regulation and emotional competence, to be used them as independent variables in more complex exploratory statistical models in order to understand more deeply the reasons why males and females present a different level of adaptation to the educational context.

\section{Conclusion}

The outcomes of our study provide interesting indications for those working in the sector, so as to help them guarantee an optimal "goodness of fit", which reconciles group context, organizational needs and individual differences. In particular, the study confirms the existence of a differential susceptibility of males and females to the context of nonparental care in infancy, to the disadvantage of males, who appear to struggle more in the adaptation processes spurred by nursery schools, where the aspects of group and peer relationships represent a major developmental challenge.

Applying the model of differential susceptibility or permeability (Belsky \& Pluess, 2009), it possible to state that males would therefore differ in their degree of permeability to environment: they appear more vulnerable, but it is necessary to investigate if they could also be those that derive the maximum evolutionary advantage 
from favorable care environments, compared to less permeable individuals, in line with recent studies that suggest, for example, that children with more difficult and reactive temperament are also able to benefit more from a positive environment like the experience of a sensitive and responsive adult (Pluess \& Belsky, 2009, 2013). This study therefore underlines the importance of investing in quality processes within nursery schools, in order to create a context that is compatible with the individual characteristics of children: this is especially true for those children who have weaker self-regulatory and stress management skills, and whose discomfort can more easily be expressed through negative social behavior and aggressiveness-related problems.

Assuming the perspective of analysis that also contemplates what happens in the "bright side" and not only in the "dark side" of development (Lionetti, Pluess, \& Barone, 2014), this model recalls the importance of paying attention to the potential for development that can be activated precisely in those children, which can be defined as permeable, for which it is necessary to strengthen the positive resources of the caregiving environment to have a positive behavioral response to well-being.

As previous studies have already reported (Gevers Deynoot-Schaub \& RiksenWalraven, 2006; Phillips et al., 2012), the quality of educator-child interactions appears particularly important, why additional research is needed to evaluate the specific role of educators' skills to help children in emotional regulation process, focusing on teachers' personal and professional emotional competence (Ciucci, Baroncelli, Toselli, \& Denham, 2018; Scarzello, Arace, Zonca, \& Agostini, 2017).

\section{References}

Achenbach, T. M., \& Rescorla, L. A. (2000). Manual for the ASEBA Preschool Forms \& Profiles. Burlington, VT: University of Vermont, Research Center for Children, Youth \& Families. 
Arace, A., Scarzello, D., \& Prino, L. E. (2018). The evaluation of behavioural problems in the first three years of life: Comparing parents and early childhood educators. Infant Behavior and Development, 50, 324-327.

Axia, G. (2002). QUIT - Questionari Italiani del Temperamento. Trento: Erickson.

Bagby, J. H., Rudd, L. C., \& Woods, M. (2005). The effects of socioeconomic diversity on the language, cognitive and social-emotional development of children from lowincome backgrounds. Early child development and care, 175(5), 395-405.

Bassa Poropat, M.T., \& Chicco, L. (2003), Percorsi formativi nella valutazione della qualità. Bergamo: Edizioni Junior.

Beijers, R., Riksen-Walraven, M., Putnam, S., de Jong, M., \& de Weerth, C. (2013). Early non-parental care and toddler behaviour problems: Links with temperamental negative affectivity and inhibitory control. Early childhood research quarterly, 28(4), 714-722.

Belsky, J., Bakermans-Kranenburg, M.J., \& van IJzendoorn, M.H. (2007). For better and for worse: differential susceptibility to environmental influences. Current Directions in Psychological Science, 16(6), 300-304.

Belsky J., \& Pluess M. (2009). Beyond diathesis stress: differential susceptibility to environmental influences. Psychological bulletin, 35 (6), 885-908.

Boca, D. Del, Pasqua, S., Suardi, S. (2015). Childcare, mothers' work and children's schooling outcomes. Families and Societies Working Papers Series, 30.

Brody, L.R., Hall, J.A. (2000), Gender, emotion, and expression. In M. Lewis \& J. M. Haviland (Eds.), Handbook of emotions (pp.338-349). New York: Guilford Press.

Broekhuizen, M.L., vanAken, M.A.G, Dubas, J.S., Mulder, H., \& Lesemanb, P.P.M. (2015), Individual differences in effects of child care quality: The role of child affective self-regulation and gender. Infant Behavior and Development, 40, 216-230.

Burchinal, M. R., Peisner-Feinberg, E., Bryant, D. M., \& Clifford, R. (2000). Children's social and cognitive development and child-care quality: Testing for differential associations related to poverty, gender, or ethnicity. Applied Developmental Science, 4(3), 149-165.

Chaplin, T.M., Cole, P.M., \& Zahn-Waxler, C. (2005), Parental socialization of emotion expression: Gender differences and relations to child adjustment, Emotion, 5(1), 8088.

Ciucci, E., Baroncelli, A., Toselli, M., \& Denham, S. A. (2018). Personal and professional emotional characteristics of early childhood teachers and their 
proneness to communicate with parents and colleagues about children's emotions. Child \& Youth Care Forum, 47 (2), 303-316.

Crick, N. R., Ostrov, J. M., \& Werner, N. E. (2006). A longitudinal study of relational aggression, physical aggression, and children's social-psychological adjustment. Journal of abnormal child psychology, 34(2), 127-138.

Crockenberg, S.C. (2003). Rescuing the baby from the bathwater: how gender and temperament (may) influence how child care affects child development, Child Development, 74(4), 1034-8.

Crockenberg, S. C., \& Leerkes, E. M. (2005). Infant temperament moderates associations between childcare type and quantity and externalizing and internalizing behaviors at 21/2 years. Infant Behavior and Development, 28(1), 20-35.

Deater-Deckard, K., Pinkerton, R., \& Scarr, S. (1996). Child care quality and children's behavioral adjustment: A four-year longitudinal study. Journal of child psychology and psychiatry, 37(8), 937-948.

Dettling, A. C., Parker, S. W., Lane, S., Sebanc, A., \& Gunnar, M. R. (2000). Quality of care and temperament determine changes in cortisol concentrations over the day for young children in childcare. Psychoneuroendocrinology, 25(8), 819-836.

D'Odorico, L., Cassibba, R., \& Buono S. (2000), Le interazioni tra pari all'asilo nido: metodi di valutazione e variabili rilevanti, Età Evolutiva, 67, 3-14.

Drugli, M.B., Solheim, E., Lydersen, S., Moe, V., Smith, L., \& Berg-Nielsen, T.S. (2018). Elevated cortisol levels in Norwegian toddlers in childcare. Early Child Development and Care, 188(12), 1684-1695.

Dunn, J., Bretherton, I., \& Munn, P. (1987). Conversations about feeling states between mothers and their young children. Developmental psychology, 23(1), 132-139.

Eaton W. O \&Enns, L. R. (1986). Sex differences in human motor activity level. Psychological Bulletin, 100(1), 19-28

Eisenberg, N., Fabes, R. A., Guthrie, I. K., \& Reiser, M. (2002). The role of emotionality and regulation in children's social competence and adjustment. In L. Pulkkinen \& A. Caspi (Eds.), Paths to successful development: personality in the life course (pp. 46-70). New York, NY: Cambridge University Press.

Eisenberg, N., \& Miller, P. A. (1987). The relation of empathy to prosocial and related behaviors. Psychological bulletin, 101(1), 91-119.

Eisenberg, N., Vaughan, J., \& Hofer, C. (2009). Temperament, self-regulation, and peer social competence. In K. H. Rubin, W. M. Bukowski, \& B. Laursen (Eds), 
Handbook of peer interactions, relationships, and groups (pp. 473-489). New York, NY: Guilford Press.

Else-Quest, N., Hyde, M., Shibley, J., Goldsmith, H.H., \& Van Hulle, C. A. (2006), Gender differences in temperament: A meta-analysis. Psychological Bulletin, 132(1), 33-72.

Emiliani, F., \& Molina, P. (2017). Interventi educativi per la prima infanzia: a chi fa bene il nido? Spunti per una riflessione e apertura di un dibattito. Interventi di Tullia Musatti e Roberto Cubelli. Psicologia clinica dello sviluppo, 21(3), 463-482.

Fabes, R. A., Hanish, L. D., \& Martin, C. L. (2003). Children at play: The role of peers in understanding the effects of child care. Child development, 74(4), 1039-1043.

Gevers Deynoot-Schaub, M. J., \& Riksen-Walraven, J. M. (2006). Peer contacts of 15month-olds in childcare: Links with child temperament, parent-child interaction and quality of childcare. Social Development, 15(4), 709-729.

Harmes, T, Cryere, D., Clifford, R.M. (1990). Scala per la Valutazione dell'Asilo Nido. Milano: Franco Angeli.

Howes, C., \& Olenick, M. (1986). Family and child care influences on toddler's compliance. Child development, 57, 202-216.

Komsi, N., Räikkönen, K., Pesonen, A. K., Heinonen, K., Keskivaara, P., Järvenpää, A. L., \& Strandberg, T. E. (2006). Continuity of temperament from infancy to middle childhood. Infant Behavior and Development, 29(4), 494-508.

Lemay, L., Bigras, N., \& Bouchard, C. (2014). Relating child care during infancy to externalizing and internalizing behaviors in toddlerhood: how specific features of child care quality matter depending on a child's gender and temperament. International Journal of Early Childhood, 46(2), 143-170.

Lionetti F., Pluess M., \& Barone L. (2014). Vulnerabilità, resilienza o differente permeabilità? Un confronto tra modelli per lo studio dell'interazione individuo ambiente. Psicologia clinica dello sviluppo, 18(2), 163-182.

Loeb, S., Bridges, M., Bassok, D., Fuller, B., \& Rumberger, R. W. (2007). How much is too much? The influence of preschool centers on children's social and cognitive development. Economics of education review, 26, 52-66.

Longobardi, E., Spataro, P., Frigerio, A., \& Rescorla, L. (2016). Gender differences in the relationship between language and social competence in preschool children. Infant Behavior and Development, 43, 1-4. 
Maccoby, E. E. (1998). The two sexes: Growing up apart, coming together (Vol. 4). Cambridge: Harvard University Press.

Martin, C. L. (1995). Stereotypes about children with traditional and nontraditional gender roles. Sex roles, 33(11-12), 727-751.

McCartney, K., Burchinal, M., Clarke-Stewart, A., Bub, K. L., Owen, M. T., Belsky, J., \& NICHD Early Child Care Research Network. (2010). Testing a series of causal propositions relating time in child care to children's externalizing behavior. Developmental Psychology, 46(1), 1-17.

Meece, J. L., \& Painter, J. (2008). Gender, self-regulation, and motivation. In D. H. Schunk \& B. J. Zimmerman (Eds.), Motivation and self-regulated learning: Theory, research, and applications (pp. 339-369). New York: Lawrence Erlbaum Associates.

Meland, A. T., Kaltvedt, E. H., \& Reikerås, E. (2016). Toddlers master every day activities in kindergarten: A gender perspective. Early Childhood Education Journal, 44(4), 349-358.

NICHD Early Child Care Research Network. (2002). Early child care and children's development prior to school entry: Results from the NICHD Study of Early Child Care. American educational research journal, 39(1), 133-164.

Phillips, D., Crowell, N. A., Sussman, A. L., Gunnar, M., Fox, N., Hane, A. A., \& Bisgaier, J. (2012). Reactive temperament and sensitivity to context in childcare. Social Development, 21(3), 628-643.

Pluess, M., \& Belsky, J. (2009), Differential susceptibility to rearing experience: The case of childcare. Journal of Child Psychology and Psychiatry, 50(4), 396-404.

Pluess, M., \& Belsky J. (2013). Vantage sensitivity: Individual differences in response to positive experiences. Psychological bulletin, 139(4), 901-916.

Poulin-Dubois, D., Serbin, L. A., Eichstedt, J. A., Sen, M. G., \& Beissel, C. F. (2002). Men Don't Put on Make-up: Toddlers' knowledge of the gender stereotyping of household activities. Social Development, 11(2), 166-181.

Scarzello, D., Arace, A., Zonca, P., \& Agostini, P. (2017, November). Non parental care e benessere: conoscenze, credenze sullo sviluppo e socializzazione emotiva in un campione di educatori di nido. Proceedings of XII Congresso Nazionale Associazione SIPSA Società italiana di Psicologia della Salute (p. 152). Firenze, Italy: Firenze University Press. 
Séguin, D. G. \& MacDonald, B. (2018). The role of emotion regulation and temperament in the prediction of the quality of social relationships in early childhood, Early child development and care, 188(8), 1147-1163.

Shpancer, N. (2006). The effects of daycare: Persistent questions, elusive answers. Early Childhood Research Quarterly, 21, 227-237.

Tallandini, M.A., \& Morsan, V. (2006). Competenza sociale e comprensione linguistica in età prescolare e scolare. Età Evolutiva, 85, 41-54.

Thomas, A., \& Chess S. (1977). Temperament and development. Oxford, England: Brunner/Mazel.

Votruba-Drzal, E., Coley, R. L., Koury, A. S., \& Miller, P. (2013). Center-based child care and cognitive skills development: Importance of timing and household resources. Journal of Educational Psychology, 105, 821-838

Votruba-Drzal, E., Coley, R. L., Maldonado-Carreño, C., Li-Grining, C. P., \& ChaseLansdale, P. L. (2010). Child care and the development of behavior problems among economically disadvantaged children in middle childhood. Child development, 81(5), 1460-1474.

Warrington, M., \& Younger, M. (2006). Raising boys' achievement in primary schools. Maidenhead, UK: Open University Press.

Watamura, S. E., Donzella, B., Alwin, J., \& Gunnar, M. R. (2003). Morning-toafternoon increases in cortisol concentrations for infants and toddlers at child care: Age differences and behavioral correlates. Child Development, 74, 1006-1020.

Weinberg, M. K., Tronick, E. Z., Cohn, J. F., \& Olson, K. L. (1999). Gender differences in emotional expressivity and self-regulation during early infancy. Developmental psychology, 35(1), 175-188.

Zahn-Waxler, C., Radke-Yarrow, M., Wagner, E., \& Chapman, M. (1992). Development of concern for others. Developmental psychology, 28(1), 126-136.

Zambrana, I. M., Ystrom, E., \& Pons, F. (2012). Impact of gender, maternal education, and birth order on the development of language comprehension: A longitudinal study from 18 to 36 months of age. Journal of Developmental and Behavioral Pediatrics, $33(2), 146-155$. 
Table 1. Descriptive statistics for the 525 children in the study.

\begin{tabular}{|l|c|c|c|c|c|c|}
\hline Measures & \multicolumn{2}{|c|}{ Total sample } & \multicolumn{2}{c|}{ Males } & \multicolumn{2}{c|}{ Females } \\
\hline Age & $\mathrm{M}=25.89$ & Range & $\mathrm{M}=25.78$ & Range & $\mathrm{M}=26.07$ & Range \\
(Months) & $(\mathrm{SD}=5.43)$ & $12-36$ & $(\mathrm{SD}=5.33)$ & $17-36$ & $(\mathrm{SD}=5.55)$ & $12-36$ \\
\hline \multirow{2}{*}{ Age of } & Within 12 & After12 & Within 12 & After 12 & Within 12 & After 12 \\
enrolment & months & months & months & months & months & months \\
& $40.6 \%$ & $59.4 \%$ & $40.1 \%$ & $59.9 \%$ & $41.3 \%$ & $58.7 \%$ \\
\hline \multirow{2}{*}{ Attendance } & Full time & Part time & Full time & Part time & Full time & Part time \\
& $71.9 \%$ & $28.1 \%$ & $72.2 \%$ & $27.8 \%$ & $71.5 \%$ & $28.5 \%$ \\
\hline
\end{tabular}


Table 2. Childcare quality.

\begin{tabular}{|l|l|l|}
\hline SVANI-SUBSCALE & Mean (standard deviation) & Range \\
\hline Furnishings and materials & $\mathrm{M}=4.494(\mathrm{SD}=0.46)$ & $3-5$ \\
\hline Routine care & $\mathrm{M}=4.588(\mathrm{SD}=0.24)$ & $4.1-5$ \\
\hline Listening and speaking & $\mathrm{M}=4.578(\mathrm{SD}=0.49)$ & $3.5-5$ \\
\hline Learning activities & $\mathrm{M}=4.277(\mathrm{SD}=0.44)$ & $3.4-5$ \\
\hline Peer-to-peer interaction and interaction between adults and children & $\mathrm{M}=4.71(\mathrm{SD}=0.45)$ & $3-5$ \\
\hline Activity organization & $\mathrm{M}=4.48(\mathrm{SD}=0.51)$ & $3-5$ \\
\hline Needs of the adults & $\mathrm{M}=4.55(\mathrm{SD}=0.37)$ & $3.5-5$ \\
\hline Overall quality score & $\mathrm{M}=4.54(\mathrm{SD}=0.28)$ & $3.8-4.9$ \\
\hline
\end{tabular}


Table 3. Social skills and behavioral problems: results for total sample, males and females.

\begin{tabular}{|c|c|c|c|c|c|c|c|}
\hline Measures & \multicolumn{2}{|c|}{ Total sample } & \multicolumn{2}{|c|}{ Males } & \multicolumn{2}{|c|}{ Females } & Anova \\
\hline $\begin{array}{l}\text { Social skills } \\
\text { (TOT) }\end{array}$ & $\begin{array}{l}\mathrm{M}=60.58 \\
(\mathrm{SD}=9.88)\end{array}$ & $\begin{array}{l}\text { Range } \\
32-86\end{array}$ & $\begin{array}{l}M=59.61 \\
(S D=9.57)\end{array}$ & $\begin{array}{l}\text { Range } \\
36-86\end{array}$ & $\begin{array}{l}M=61.78 \\
(S D=10.15)\end{array}$ & $\begin{array}{l}\text { Range } \\
32-84\end{array}$ & $\begin{array}{l}F_{(1,480)}=5.777 \\
\mathbf{P}<\mathbf{0 . 0 5}\end{array}$ \\
\hline $\begin{array}{l}\text { Negative } \\
\text { social } \\
\text { behaviors }\end{array}$ & $\begin{array}{l}M=13.44 \\
(S D=2.78)\end{array}$ & $\begin{array}{l}\text { Range } \\
7-24\end{array}$ & $\begin{array}{l}M=13.7 \\
(S D=2.61)\end{array}$ & $\begin{array}{l}\text { Range } \\
7-24\end{array}$ & $\begin{array}{l}M=13.11 \\
(\mathrm{SD}=2.97)\end{array}$ & $\begin{array}{l}\text { Range } \\
7-24\end{array}$ & $\begin{array}{l}F_{(1,507)}=5.588 \\
\mathbf{P}<\mathbf{0 . 0 5}\end{array}$ \\
\hline $\begin{array}{l}\text { Positive } \\
\text { social } \\
\text { behaviors }\end{array}$ & $\begin{array}{l}M=11.64 \\
(S D=3.16)\end{array}$ & $\begin{array}{l}\text { Range } \\
6-20\end{array}$ & $\begin{array}{l}M=11.21 \\
(\mathrm{SD}=3.14)\end{array}$ & $\begin{array}{l}\text { Range } \\
6-20\end{array}$ & $\begin{array}{l}\mathrm{M}=12.17 \\
(\mathrm{SD}=3.11)\end{array}$ & $\begin{array}{l}\text { Range } \\
6-19\end{array}$ & $\begin{array}{l}\mathrm{F}_{(1,506)}=11.69 \\
\mathbf{P}=\mathbf{0 . 0 0 1}\end{array}$ \\
\hline $\begin{array}{l}\text { Difficulty in } \\
\text { participation }\end{array}$ & $\begin{array}{l}M=9.06 \\
(\mathrm{SD}=2.73)\end{array}$ & $\begin{array}{l}\text { Range } \\
5-19\end{array}$ & $\begin{array}{l}\mathrm{M}=9.28 \\
(\mathrm{SD}=2.71)\end{array}$ & $\begin{array}{l}\text { Range } \\
5-19\end{array}$ & $\begin{array}{l}\mathrm{M}=8.8 \\
(\mathrm{SD}=2.87)\end{array}$ & $\begin{array}{l}\text { Range } \\
5-19\end{array}$ & $\begin{array}{l}F_{(1,506)}=3.95 \\
\mathbf{P}<\mathbf{0 . 0 5}\end{array}$ \\
\hline Popularity & $\begin{array}{l}\mathrm{M}=11.41 \\
(\mathrm{SD}=3.61)\end{array}$ & $\begin{array}{l}\text { Range } \\
5-20\end{array}$ & $\begin{array}{l}\mathrm{M}=11.25 \\
(\mathrm{SD}=3.62)\end{array}$ & $\begin{array}{l}\text { Range } \\
5-20\end{array}$ & $\begin{array}{l}M=11.62 \\
(\mathrm{SD}=3.58)\end{array}$ & $\begin{array}{l}\text { Range } \\
5-20\end{array}$ & $\begin{array}{l}\mathrm{F}_{(1,493)}=1.291 \\
\mathrm{P}=\text { n.s. }\end{array}$ \\
\hline
\end{tabular}


Table 4. CBCL: results for total sample, males and females.

\begin{tabular}{|c|c|c|c|c|c|c|c|}
\hline Measures & \multicolumn{2}{|c|}{ Total sample } & \multicolumn{2}{|c|}{ Males } & \multicolumn{2}{|c|}{ Females } & Anova \\
\hline $\begin{array}{l}\text { CBCL-Total } \\
\text { Scale }\end{array}$ & $\begin{array}{l}\mathrm{M}=27.37 \\
(\mathrm{SD}=18.54)\end{array}$ & $\begin{array}{l}\text { Range } \\
0-106\end{array}$ & $\begin{array}{l}\mathrm{M}=30.44 \\
(\mathrm{SD}=20.3)\end{array}$ & $\begin{array}{l}\text { Range } \\
0-106\end{array}$ & $\begin{array}{l}M=23.66 \\
(S D=15.43)\end{array}$ & $\begin{array}{l}\text { Range } \\
0-81\end{array}$ & $\begin{array}{l}\mathrm{F}_{(1,403)}=13.8 \\
\mathbf{P}<\mathbf{0 . 0 0 1}\end{array}$ \\
\hline Internalizing & $\begin{array}{l}\mathrm{M}=8.61 \\
(\mathrm{SD}=6.88)\end{array}$ & $\begin{array}{l}\text { Range } \\
0-37\end{array}$ & $\begin{array}{l}\mathrm{M}=9.24 \\
(\mathrm{SD}=7.35)\end{array}$ & $\begin{array}{l}\text { Range } \\
0-29\end{array}$ & $\begin{array}{l}\mathrm{M}=7.83 \\
(\mathrm{SD}=6.17)\end{array}$ & $\begin{array}{l}\text { Range } \\
0-37\end{array}$ & $\begin{array}{l}F_{(1,488)}=5.116 \\
\mathbf{P}<\mathbf{0 . 0 5}\end{array}$ \\
\hline Externalizing & $\begin{array}{l}M=12.19 \\
(S D=10.42)\end{array}$ & $\begin{array}{l}\text { Range } \\
0-49\end{array}$ & $\begin{array}{l}M=13.56 \\
(S D=11)\end{array}$ & $\begin{array}{l}\text { Range } \\
0-49\end{array}$ & $\begin{array}{l}M=10.51 \\
(S D=9.43)\end{array}$ & $\begin{array}{l}\text { Range } \\
0-46\end{array}$ & $\begin{array}{l}F_{(1,469)}=10.092 \\
\mathbf{P}<\mathbf{0 . 0 0 5}\end{array}$ \\
\hline $\mathrm{W}$ & $\begin{array}{l}\mathrm{M}=2.74 \\
(\mathrm{SD}=3.08)\end{array}$ & $\begin{array}{l}\text { Range } \\
0-18\end{array}$ & $\begin{array}{l}\mathrm{M}=3.02 \\
(\mathrm{SD}=3.24)\end{array}$ & $\begin{array}{l}\text { Range } \\
0-18\end{array}$ & $\begin{array}{l}\mathrm{M}=2.38 \\
(\mathrm{SD}=2.83)\end{array}$ & $\begin{array}{l}\text { Range } \\
0-16\end{array}$ & $\begin{array}{l}F_{(1,504)}=5.485 \\
\mathbf{P}<\mathbf{0 . 0 5}\end{array}$ \\
\hline AP & $\begin{array}{l}\mathrm{M}=4.04 \\
(\mathrm{SD}=3.71)\end{array}$ & $\begin{array}{l}\text { Range } \\
0-20\end{array}$ & $\begin{array}{l}\mathrm{M}=4.69 \\
(\mathrm{SD}=3.87)\end{array}$ & $\begin{array}{l}\text { Range } \\
0-20\end{array}$ & $\begin{array}{l}\mathrm{M}=3.22 \\
(\mathrm{SD}=3.31)\end{array}$ & $\begin{array}{l}\text { Range } \\
0-16\end{array}$ & $\begin{array}{l}\mathrm{F}_{(1,500)}=20.079 \\
\mathbf{P}<\mathbf{0 . 0 0 1}\end{array}$ \\
\hline $\mathrm{AB}$ & $\begin{array}{l}\mathrm{M}=8.15 \\
(\mathrm{SD}=7.43)\end{array}$ & $\begin{array}{l}\text { Range } \\
0-38\end{array}$ & $\begin{array}{l}\mathrm{M}=8.95 \\
(\mathrm{SD}=7.88)\end{array}$ & $\begin{array}{l}\text { Range } \\
0-38\end{array}$ & $\begin{array}{l}\mathrm{M}=7.17 \\
(\mathrm{SD}=6.72)\end{array}$ & $\begin{array}{l}\text { Range } \\
0-33\end{array}$ & $\begin{array}{l}F_{(1,482)}=6.87 \\
\mathbf{P}=\mathbf{0 . 0 1}\end{array}$ \\
\hline $\mathrm{OP}$ & $\begin{array}{l}\mathrm{M}=7.24 \\
(\mathrm{SD}=4.69)\end{array}$ & $\begin{array}{l}\text { Range } \\
0-34\end{array}$ & $\begin{array}{l}\mathrm{M}=7.89 \\
(\mathrm{SD}=5.12)\end{array}$ & $\begin{array}{l}\text { Range } \\
0-34\end{array}$ & $\begin{array}{l}\mathrm{M}=6.43 \\
(\mathrm{SD}=3.95)\end{array}$ & $\begin{array}{l}\text { Range } \\
0-26\end{array}$ & $\begin{array}{l}\mathrm{F}_{(1,444)}=10.875 \\
\mathbf{P}=\mathbf{0 . 0 0 1}\end{array}$ \\
\hline ER & $\begin{array}{l}\mathrm{M}=2.28 \\
(\mathrm{SD}=2.13)\end{array}$ & $\begin{array}{l}\text { Range } \\
0-13\end{array}$ & $\begin{array}{l}\mathrm{M}=2.28 \\
(\mathrm{SD}=2.21)\end{array}$ & $\begin{array}{l}\text { Range } \\
0-13\end{array}$ & $\begin{array}{l}\mathrm{M}=2.15 \\
(\mathrm{SD}=2.04)\end{array}$ & $\begin{array}{l}\text { Range } \\
0-10\end{array}$ & $\begin{array}{l}\mathrm{F}_{(1,516)}=0.453 \\
\mathrm{P}=\mathrm{n} . \mathrm{s} .\end{array}$ \\
\hline $\mathrm{SC}$ & $\begin{array}{l}\mathrm{M}=0.54 \\
(\mathrm{SD}=0.92)\end{array}$ & $\begin{array}{l}\text { Range } \\
0-5\end{array}$ & $\begin{array}{l}\mathrm{M}=0.61 \\
(\mathrm{SD}=0.97)\end{array}$ & $\begin{array}{l}\text { Range } \\
0-4\end{array}$ & $\begin{array}{l}\mathrm{M}=0.46 \\
(\mathrm{SD}=0.84)\end{array}$ & $\begin{array}{l}\text { Range } \\
0-5\end{array}$ & $\begin{array}{l}\mathrm{F}_{(1,517)}=3.247 \\
\mathrm{P}=\text { n.s. }\end{array}$ \\
\hline $\mathrm{AD}$ & $\begin{array}{l}\mathrm{M}=3.09 \\
(\mathrm{SD}=2.66)\end{array}$ & $\begin{array}{l}\text { Range } \\
0-13\end{array}$ & $\begin{array}{l}\mathrm{M}=3.27 \\
(\mathrm{SD}=2.8)\end{array}$ & $\begin{array}{l}\text { Range } \\
0-13\end{array}$ & $\begin{array}{l}\mathrm{M}=2.86 \\
(\mathrm{SD}=2.47)\end{array}$ & $\begin{array}{l}\text { Range } \\
0-10\end{array}$ & $\begin{array}{l}\mathrm{F}_{(1,512)}=2.926 \\
\mathrm{P}=\mathrm{n} . \mathrm{s}\end{array}$ \\
\hline
\end{tabular}


Table 5. Correlations between Age, QPI and CBCL scales.

\begin{tabular}{lccccc} 
& Age & $\begin{array}{c}\text { Social skills- } \\
\text { TOT }\end{array}$ & $\begin{array}{c}\text { CBCL-Total } \\
\text { scale }\end{array}$ & Internalizing & Externalizing \\
\hline Age & 1 & $0.326^{* *}$ & 0.075 & 0.064 & 0.065 \\
\hline $\begin{array}{l}\text { Social skills- } \\
\text { TOT }\end{array}$ & $0.340^{* *}$ & 1 & $-0.362^{* *}$ & $-0.432^{* *}$ & $-0.188^{* *}$ \\
\hline $\begin{array}{l}\text { CBCL-Total } \\
\text { scale }\end{array}$ & -0.109 & $-0.475^{* *}$ & 1 & $0.769^{* *}$ & $0.897^{* *}$ \\
\hline Internalizing & 0.022 & $-0.404^{* *}$ & $0.736^{* *}$ & 1 & $0.421^{* *}$ \\
\hline Externalizing & -0.126 & $-0.362^{* *}$ & $0.847^{* *}$ & $0.365^{* *}$ & 1 \\
\hline Key: **p<0.01 & & & &
\end{tabular}

Data under the diagonal refer to females; data over the diagonal refer to males. 
Table 6. Effects of age of enrolment and daycare attendance on social skills and behavioral problems in males and females.

\begin{tabular}{|c|c|c|c|c|c|c|c|c|}
\hline Measures & \multicolumn{4}{|c|}{ Males } & \multicolumn{4}{|c|}{ Females } \\
\hline \multirow{3}{*}{$\begin{array}{l}\text { Social skills- } \\
\quad \text { TOT }\end{array}$} & $\begin{array}{c}\text { Enrolment } \\
\text { before } 12 \\
\text { months }\end{array}$ & $\begin{array}{l}\text { Enrolment } \\
\text { after } 12 \\
\text { months }\end{array}$ & Part time & Full time & $\begin{array}{c}\text { Enrolment } \\
\text { before } 12 \\
\text { months }\end{array}$ & $\begin{array}{l}\text { Enrolment } \\
\text { after } 12 \\
\text { months }\end{array}$ & Part time & Full time \\
\hline & $\begin{array}{l}\mathrm{M}=60.79 \\
(\mathrm{SD}=9.36)\end{array}$ & $\begin{array}{c}\mathrm{M}=58.83 \\
(\mathrm{SD}=9.68)\end{array}$ & $\begin{array}{l}\mathrm{M}=58.58 \\
(\mathrm{SD}=9.8)\end{array}$ & $\begin{array}{c}\mathrm{M}=60.28 \\
(\mathrm{SD}=9.43)\end{array}$ & $\begin{array}{c}\mathrm{M}=64.11 \\
(\mathrm{SD}=10.38)\end{array}$ & $\begin{array}{l}\mathrm{M}=60.18 \\
(\mathrm{SD}=9.79)\end{array}$ & $\begin{array}{l}\mathrm{M}=58.2 \\
(\mathrm{SD}=9.2)\end{array}$ & $\begin{array}{c}\mathrm{M}=62.81 \\
(\mathrm{SD}=10.28)\end{array}$ \\
\hline & \multicolumn{2}{|c|}{$\begin{array}{c}\mathrm{F}_{(1,264)}=2.696 \\
\mathrm{P}=\text { n.s. }\end{array}$} & \multicolumn{2}{|c|}{$\begin{array}{c}\mathrm{F}_{(1,247)}=1.559 \\
\mathrm{P}=\text { n.s. }\end{array}$} & \multicolumn{2}{|c|}{$\begin{array}{c}\mathrm{F}_{(1,212)}=7.887 \\
\mathbf{P}=\mathbf{0 . 0 0 5}\end{array}$} & \multicolumn{2}{|c|}{$\begin{array}{c}\mathrm{F}_{(1,198)}=8.469 \\
\mathbf{P}<\mathbf{0 . 0 0 5}\end{array}$} \\
\hline \multirow{2}{*}{$\begin{array}{l}\text { CBCL-Total } \\
\quad \text { Scale }\end{array}$} & $\begin{array}{c}\mathrm{M}=30.18 \\
(\mathrm{SD}=20.94)\end{array}$ & $\begin{array}{c}\mathrm{M}=30.62 \\
(\mathrm{SD}=19.93) \\
\end{array}$ & $\begin{array}{c}\mathrm{M}=24.42 \\
(\mathrm{SD}=16.61)\end{array}$ & $\begin{array}{c}\mathrm{M}=32.25 \\
(\mathrm{SD}=21.23)\end{array}$ & $\begin{array}{c}\mathrm{M}=22.88 \\
(\mathrm{SD}=15.39)\end{array}$ & $\begin{array}{l}\mathrm{M}=24.33 \\
(\mathrm{SD}=15.6)\end{array}$ & $\begin{array}{c}\mathrm{M}=25.79 \\
(\mathrm{SD}=13.35)\end{array}$ & $\begin{array}{c}\mathrm{M}=22.35 \\
(\mathrm{SD}=15.58)\end{array}$ \\
\hline & \multicolumn{2}{|c|}{$\begin{array}{c}\mathrm{F}_{(1,220)}=0.025 \\
\mathrm{P}=\text { n.s. }\end{array}$} & \multicolumn{2}{|c|}{$\begin{array}{c}\mathrm{F}_{(1,205)}=6.186 \\
\mathbf{P}<\mathbf{0 . 0 5}\end{array}$} & \multicolumn{2}{|c|}{$\begin{array}{c}\mathrm{F}_{(1,180)}=0.388 \\
\mathrm{P}=\text { n.s. }\end{array}$} & \multicolumn{2}{|c|}{$\begin{array}{c}\mathrm{F}_{(1,167)}=1.808 \\
\mathrm{P}=\text { n.s. }\end{array}$} \\
\hline \multirow[b]{2}{*}{ Internalizing } & $\begin{array}{c}\mathrm{M}=8.34 \\
(\mathrm{SD}=6.93)\end{array}$ & $\begin{array}{c}\mathrm{M}=9.83 \\
(\mathrm{SD}=7.61)\end{array}$ & $\begin{array}{l}\mathrm{M}=8.44 \\
(\mathrm{SD}=7)\end{array}$ & $\begin{array}{c}\mathrm{M}=9.32 \\
(\mathrm{SD}=7.46)\end{array}$ & $\begin{array}{c}\mathrm{M}=7 \\
(\mathrm{SD}=5.11)\end{array}$ & $\begin{array}{c}\mathrm{M}=8.49 \\
(\mathrm{SD}=6.81)\end{array}$ & $\begin{array}{c}\mathrm{M}=8.46 \\
(\mathrm{SD}=5.91)\end{array}$ & $\begin{array}{c}\mathrm{M}=7.46 \\
(\mathrm{SD}=6.21)\end{array}$ \\
\hline & \multicolumn{2}{|c|}{$\begin{array}{c}\mathrm{F}_{(1,268)}=2.68 \\
\mathrm{P}=\text { n.s. }\end{array}$} & \multicolumn{2}{|c|}{$\begin{array}{c}\mathrm{F}_{(1,250)}=0.703 \\
\mathrm{P}=\text { n.s. }\end{array}$} & \multicolumn{2}{|c|}{$\begin{array}{c}\mathrm{F}_{(1,216)}=3.095 \\
\mathrm{P}=\text { n.s. }\end{array}$} & \multicolumn{2}{|c|}{$\begin{array}{c}\mathrm{F}_{(1,202)}=1.108 \\
\mathrm{P}=\text { n.s. }\end{array}$} \\
\hline \multirow{2}{*}{ Externalizing } & $\begin{array}{c}\mathrm{M}=13.90 \\
(\mathrm{SD}=11.64)\end{array}$ & $\begin{array}{c}\mathrm{M}=13.34 \\
(\mathrm{SD}=10.58)\end{array}$ & $\begin{array}{c}\mathrm{M}=11.27 \\
(\mathrm{SD}=9.27)\end{array}$ & $\begin{array}{c}\mathrm{M}=14.27 \\
(\mathrm{SD}=11.37)\end{array}$ & $\begin{array}{c}\mathrm{M}=10.44 \\
(\mathrm{SD}=9.41)\end{array}$ & $\begin{array}{l}M=10.56 \\
(\mathrm{SD}=9.54)\end{array}$ & $\begin{array}{c}\mathrm{M}=10.38 \\
(\mathrm{SD}=9.02)\end{array}$ & $\begin{array}{c}\mathrm{M}=10.38 \\
(\mathrm{SD}=9.45)\end{array}$ \\
\hline & \multicolumn{2}{|c|}{$\begin{array}{c}\mathrm{F}_{(1,258)}=0.166 \\
\mathrm{P}=\text { n.s. }\end{array}$} & \multicolumn{2}{|c|}{$\begin{array}{c}\mathrm{F}_{(1,241)}=3.673 \\
\mathbf{P}=\mathbf{0 . 0 5}\end{array}$} & \multicolumn{2}{|c|}{$\begin{array}{c}\mathrm{F}(1,208)=0.08 \\
\mathrm{P}=\text { n.s. }\end{array}$} & \multicolumn{2}{|c|}{$\begin{array}{c}\mathrm{F}_{(1,193)}=0.000 \\
\mathrm{P}=\text { n.s. }\end{array}$} \\
\hline
\end{tabular}


Table 7. Temperament according to mothers.

\begin{tabular}{|l|c|c|c|c|c|c|l|}
\hline Measures & \multicolumn{2}{|c|}{ Total sample } & \multicolumn{2}{c|}{ Males } & \multicolumn{2}{c|}{ Females } & Anova \\
\hline Social & $\mathrm{M}=37.07$ & Range & $\mathrm{M}=36.78$ & Range & $\mathrm{M}=37.44$ & Range & $\mathrm{F}_{(1,495)}=1.771$ \\
Orientation & $(\mathrm{SD}=5.44)$ & $21-53$ & $(\mathrm{SD}=5.23)$ & $21-53$ & $(\mathrm{SD}=5.69)$ & $22-51$ & $\mathrm{P}=$ n.s. \\
\hline Inhibition to & $\mathrm{M}=32.94$ & Range & $\mathrm{M}=31.89$ & Range & $\mathrm{M}=34.26$ & Range & $\mathrm{F}_{(1,491)}=8.553$ \\
novelties & $(\mathrm{SD}=8.99)$ & $14-64$ & $(\mathrm{SD}=8.55)$ & $14-61$ & $(\mathrm{SD}=9.37)$ & $15-64$ & $\mathbf{P}<\mathbf{0 . 0 0 5}$ \\
\hline Motor & $\mathrm{M}=37.65$ & Range & $\mathrm{M}=38.10$ & Range & $\mathrm{M}=37.08$ & Range & $\mathrm{F}_{(1,449)=2.581}$ \\
activity & $(\mathrm{SD}=6.69)$ & $19-57$ & $(\mathrm{SD}=6.41)$ & $25-55$ & $(\mathrm{SD}=7.02)$ & $19-57$ & $\mathrm{P}=$ n.s. \\
\hline Positive & $\mathrm{M}=46.56$ & Range & $\mathrm{M}=46.53$ & Range & $\mathrm{M}=46.59$ & Range & $\mathrm{F}_{(1,486)}=0.16$ \\
emotionality & $(\mathrm{SD}=5.56)$ & $30-59$ & $(\mathrm{SD}=5.33)$ & $32-58$ & $(\mathrm{SD}=5.85)$ & $30-59$ & $\mathrm{P}=$ n.s. \\
\hline Negative & $\mathrm{M}=17.44$ & Range & $\mathrm{M}=17.06$ & Range & $\mathrm{M}=17.93$ & Range & $\mathrm{F}(1,498)=3.453$ \\
emotionality & $(\mathrm{SD}=5.16)$ & $6-45$ & $(\mathrm{SD}=5.2)$ & $6-45$ & $(\mathrm{SD}=5.08)$ & $7-34$ & $\mathrm{P}=\mathrm{n} . \mathrm{s}$. \\
\hline \multirow{2}{*}{ Attention } & $\mathrm{M}=34.86$ & Range & $\mathrm{M}=34.75$ & Range & $\mathrm{M}=35.01$ & Range & $\mathrm{F}(1,501)=0.397$ \\
& $(\mathrm{SD}=4.48)$ & $21-47$ & $(\mathrm{SD}=4.53)$ & $22-47$ & $(\mathrm{SD}=4.41)$ & $21-44$ & $\mathrm{P}=$ n.s. \\
\hline
\end{tabular}

